\title{
Speciális ellátást igénylő páciensek orális egészsége Összefoglaló referátum
}

\author{
DR. ORSÓS MERCÉDESZ, DR. MOLDVAI JÚLIA, DR. NÉMETH ORSOLYA
}

\begin{abstract}
A világon több mint 1 milliárd ember él valamilyen fogyatékkal. Ezeket az embereket speciális ellátást igénylő páciensek közé soroljuk, hiszen a funkcióveszteség következményeként nehezített a szájhigiéniás rutin és a rendszeres fogorvosi kontroll. Az irodalomban található adatok alapján a speciális ellátást igénylő betegek szájhigiéniás állapota rossz, ennek oka, hogy fogászati terápiájuk, gondozásuk nem megoldott a mindennapi gyakorlatban.
\end{abstract}

Kulcsszó: speciális ellátás, fogyatékosság, funkcióvesztés, szájhigiénia, dentális rehabilitáció

\section{Speciális ellátást igénylö páciensek, fogyatékosság, rehabilitáció}

A világon közel 1 milliárd ember él valamilyen fogyatékkal, a 2011-es népszámlálási adatok alapján Magyarország lakosságának 4,6\%-a, megközelítőleg 500.000 ember [19, 21]. Az elöregedésnek köszönhetően egyre gyakoribbá válnak a krónikus megbetegedések. Ezek következményei, illetve veleszületett kórképek miatt, valamint a balesetben sérült, maradandó károsodást szenvedett betegek nem képesek önállóan fenntartani a napi szájhigiéniás rutint. Számukra a fogorvosi rendelő elérése is akadályozott lehet [3]. Öket fogászati szempontból a speciális ellátást igénylő páciensek közé soroljuk.

A speciális ellátást igénylő betegek irodalma széles, viszont ezek többsége az általános orvosi gyakorlattal foglalkozik. A fogorvosi aspektussal, a szájüregi rehabilitációval és a szájhigiénia fenntartásával csak kevés publikációban találkozunk. Pedig az orvoslás ezen része is egy interdiszciplináris terület, a fogorvoslásnak is részének kell lennie.

Elsőként tisztáznunk kell, kik tartoznak a speciális ellátást igénylők közé. Korábban a fogyatékossághoz vezető utat a következő folyamattal írta le a WHO 1980-as osztályozása: a betegség vagy rendellenesség után fellép a biológiai múködés szervszintú zavara, kialakul a károsodás, sérülés. A károsodás következménye a személy szintjén jelentkező funkciózavar, a fogyatékosság. Ezenkívül a személy szociális szerepében is zavar következik be, hiszen az őt körülvevő környezethez való alkalmazkodásban hátrányt szenved [8]. 2001-ben a WHO módosította a fogyatékosság definícióját és létrehozott egy új osztályozást: The International Classification of Functioning, Disability and Health (ICF) - a funkcióképesség, fogyatékosság és egészség nemzetközi osztá- lyozása. A fogyatékosság mint gyújtőfogalom szerepel; nem egyenes irányú folyamatok, hanem kölcsönhatások jönnek létre, melyek közé tartozik a testi funkciók károsodása, a tevékenység akadályozottá, a társadalmi életben való részvétel korlátozottá válása [25]. Az új klasszifikáció magyar megfelelője a Funkcionális állapotok Nemzetközi Osztályozása (FNO) [6].

Hazánkban a jelenleg hatályos 1998. évi XXVI. törvény alapján „fogyatékos személy: az a személy, aki tartósan vagy véglegesen olyan érzékszervi, kommunikációs, fizikai, értelmi, pszichoszociális károsodással - illetve ezek bármilyen halmozódásával - él, amely a környezeti, társadalmi és egyéb jelentős akadályokkal kölcsönhatásban a hatékony és másokkal egyenlö társadalmi részvételt korlátozza vagy gátolja" [22].

A fogyatékkal élők heterogén csoportot hoznak létre, így nem oszthatjuk őket „klasszikus” csoportokba, hiszen az egészségi álapotuk mellett a környezet és a személyes faktorok befolyásolják státuszukat [16].

\section{Fogászati aspektus}

Átfogó, az egész világra kiterjedő vizsgálat még nem történt, ami a szájüregi betegségek és a fogyatékosság közötti összefüggést nézné. Viszont több kisebb regionális adat azt mutatja, hogy ezen betegcsoport tagjai szignifikánsan rosszabb szájüregi állapottal rendelkeznek, ezenkívül nehezítettebbek a fogászati ellátás elérésében [18]. Ez az akadály lehet például a rendelőbe jutás, az odaszállítás költsége, illetve az, hogy az ellátást végző fogorvosok nem rendelkeznek kellő tapasztalattal [7]. Ez részben azzal magyarázható, hogy a fogyatékkal élő betegek ellátásának ismerete egyelőre nem része a fogorvosképzés kurrikulumának. Magyar- 
országon az akadálymentesítés megvalósítására, a Széchenyi 2020 program keretén belül, az Európiai Unió és a hazai költségvetés támogatásával, 12 milliárd forint fejlesztési forrás felhasználása vált elérhetővé [24]. Az Emberi Erőforrások Minisztériuma listázta a fogyatékkal élők speciális egészségügyi ellátására szóló finanszírozási szerződéssel működő fogászatokat [20].

Sok esetben a speciális ellátást igénylő páciensek általános állapota jelenti a legfőbb nehézséget a fogorvosok számára. Komplex orvosi kezelés alatt állnak, ezért a fogászati beavatkozást a kezelőorvossal való konzultáció előzi meg. A leggyakoribb általános betegségek, amelyek komplikációt okozhatnak a fogászati beavatkozások során: a szív és érrendszeri betegségek, cukorbetegség, immunhiánnyal járó betegségek, osteoporosis, agyi történések és malignus elváltozások. $A$ beavatkozások során komoly kockázatot jelentenek a szedett gyógyszerek, különösképp a véralvadásgátlók. A meglévő általános betegségek mellett fontos figyelembe venni a páciensek pszichés állapotát is, ami hatással lehet a kooperációs képességekre és a kezelések időzítésére [5]. Ezen betegek többségénél megfigyelhetők a szorongás jelei, ez okozhat fizikai, kognitív és viselkedésbeli tüneteket. A szorongás pedig növeli a depresszió kockázatát [9]. Mentális állapotuk negatív hatással lehet a mindennapi élet feladatainak elvégzésére, így ennek legyőzése is célja az orvosi rehabilitációnak. A fent említett problémák leküzdése mellett a speciális ellátást igénylő páciensek esetében további nehézséget okozhatnak a kezelés során az agyi sérülések által kialakuló dysphagia, aphasia, verbális apraxia, ami nagyban korlátozza a megfelelő kommunikációt. Ilyenkor jó megoldást jelenthetnek a piktogramokkal ellátott magyarázó táblák.

\section{Szájhigiénia}

A speciális ellátást igénylő betegek pszichés állapota és az általános betegségekből eredő mozgáskorlátozottság, valamint a szedett gyógyszerek mellékhatásai nagymértékben megnehezítik a megfelelő szájhigiénia kialakítását, fenntartását. A manuális funkciók csökkenése, illetve kiesése nehezíti az optimális fogmosási technika kivitelezését, már a fogkefe megragadása is problémát okozhat, valamint a kivehető pótlások tisztítása is nehezített. Ezért ezen betegeknél a dentális plakk mennyisége nagymértékben megnő, amely növeli a fogszuvasodás, parodontális problémák, bakteriális és gombás fertőzések megjelenésének esélyét. A páciensek által szedett gyógyszerek miatt kialakult xerostomia növeli a baktériumok és gombák elszaporodásának lehetőségét [10].

Az izombénulás által nehezítetté válhat a táplálkozás, rágás és a nyelés is, ami által az étel tovább maradhat a szájüregben, ezzel fokozva a fogszuvasodás kialakulásának esélyeit [23].

A funkcióvesztés fokától függően a fogyatékossággal élők részben vagy teljes egészében elvesztették önál- lóságukat. Többségük gondozásra szorul, amelyet hozzátartozók, ápolók, gondozók biztosítanak számukra, nagyrészük nem rendelkezik szájhigiéniára vonatkozó ismeretekkel. A gondozók jelentős része akkor tartja fontosnak a fogorvosi kontrollt, ha a beteg már fájdalomra panaszkodik, holott tisztában vannak vele, hogy a nem megfelelő szájhigiénia hatással van az általános egészségi állapotra [17]. A prevenciónak esetükben egyénre szabottan kell megvalósulnia, a gondozóknak az általános szájhigiéniás rutinon túl fel kell mérniük a beteg egyéni igényeit és képességeit.

Ezen betegcsoport a hagyományos szájápolási termékekkel nehezebben vagy egyáltalán nem képes a megfelelő szájhigiénia fenntartására. A fogkefe megragadása, megtartása és mozgatása is nehézkes lehet. Segítséget nyújtanak a módosított, vastagabb markolatú fogkefék, melyek akár egyedi igényeknek megfelelően házilag is elkészíthetők. Léteznek előre gyártott múanyag markolatok, kiegészítő pántok, illetve több fejü fogkefék. Kar- és vállmozgásban korlátozott pácienseknek a hosszabb nyelü változatok jelentenek megoldást. A kiesett manuális funkciókat helyettesítheti az elektromos fogkefe rotáló-oszcilláló mozgása. A demenciával, koncentráció- és memóriazavarral küzdő betegek számára nagy segítség az időzítők használata [4]. A mechanikai tisztítást nem helyettesítheti, de kiegészítheti kémiai plakk-kontroll. Hosszútávon, akár 2-3 hónapig, a 0,05\% chlorhexidin tartalmú szájöblögetők használata nyújthat megoldást [3].

\section{Felmérések}

Fogyatékkal élő betegek fogászati állapotának jó indikátora a DMF-T szám. A DMF-T szám egy olyan kvantitatív mérőszám, mely megadja a szuvas, a hiányzó és a tömött fogak számát. Magyarországot tekintve, felnőtt populációra vonatkozó felmérések történtek 1985-ben (DMF-T: 15,8), 1991-ben (DMF-T: 15,0), 2000-ben (DMF-T: 15,7) és 2004-ben (DMF-T: 15,4) [11]. Hazánkban átfogó vizsgálat zajlik az Országos Orvosi Rehabilitációs Intézet (OORI) és a Fogászati és Szájsebészeti Oktató Intézet (FSZOI) együttműködésével. Az OORI-ban bent fekvő, rehabilitáció alatt álló betegek széles spektrumát lefedik a speciális ellátást igénylőknek. Fogászati állapotuk felmérése és stomato-onkológiai szürése, valamint szükség esetén kezelésük is megtörténik. Szájhigiénés rutin, fogorvoshoz járási gyakoriság, étkezési szokások, káros szenvedélyek és szociális háttér kerül felmérésre [12, 14]. Az Országos Orvosi Rehabilitációs Intézetben megvizsgált felnőtt páciensek DMF-T értéke 20,5, ezt összehasonlítva a magyar átlag felnőtt populáció értékeivel szignifikáns különbség fedezhető fel [12]. A külföldi szakirodalomban átfogó speciális ellátást igénylő páciensekre vonatkozó értékek nem találhatók, ezen kutatások a legtöbb esetben specifikus betegcsoportokat vizsgálnak (stroke utáni állapot, gerincvelősérülést követő állapot, értelmi fogyatékosok). Ezeket az eredményeket megvizs- 
gálva elmondhatjuk, hogy a fogyatékossággal élők DMF-T, szájhigiéniás és életminőségre vonatkozó értékei az átlagpopulációhoz viszonyítva rosszabbak [1, 2, 10, 15].

\section{Összefoglalás}

A szakirodalomban megtalálható kutatások eredményei alátámasztják a feltevést, miszerint a fogyatékossággal élők dentális állapota, szájhigiéniája és életminősége rosszabb, mint az átlagpopulációé, gondozásuk nem megoldott. Eddig nem születtek protokollok, irányelvek, melyek segítenék a megfelelő szájhigiénés rutin kialakítását, fenntartását.

Komplex egészségügyi problémával küzdő, illetve fogyatékossággal élő páciensek kezelése és gondozás interdiszciplináris feladat, melyben a fogorvosoknak és dentálhigiénikusoknak is kiemelkedő szerepe van. A betegek életminőség javulásában nem elhanyagolható a szájüregi rehabilitáció. A speciális ellátást igénylők orális egészségével kapcsolatban a kutatások döntő hányada rossz szájhigiéniás állapotról számol be. A jövőben ezen kutatásokra támaszkodva prevenciós stratégiák kidologzása lenne célszerú.

Anyagi támogatás: A cikk megírása nem részesült anyagi támogatásban.

Szerzői munkamegosztás: O. M., M. J.: A referátum megírása. N. O.: A referátum szerkeztése. A cikk végleges változatát valamennyi szerző elolvasta és jóváhagyta. Érdekeltségek: A szerzőknek nincsenek érdekeltségeik.

\section{Irodalom}

1. Anders PL, Davis EL: Oral health of patients with intellectual disabilities: a systematic review. Spec Care Dentist. 2010 May-Jun; 30 (3): 110-107.

2. Costa A, Della Bona A, Trentin M: Influence of Different Intellectual Disability Levels on Caries and Periodontal Disease. Braz Dent J. 2016 Jan-Feb; 27 (1): 52-55.

3. Dougall A, Fiske J: Access to special care dentistry, part 1. Access Br Dent J. 2008 Jun 14; 204 (11): 605-616.

4. Dougall A, Fiske J: Access to special care dentistry, part 4. Education. Br Dent J. 2008 Aug 9; 205 (3): 119-130.

5. Fejérdy P, NaGy G, Orosz M: Gerosztomatológia. Semmelweis Kiadó, Budapest, 2007, 64.

6. Fogyatékosságtudományi tanulmányok XX.: Funkcióképesség, fogyatékosság és egészség nemzetközi osztályozása. Eötvös Ló- ránd Tudományegyetem - Bárczi Gusztáv Gyógypedagógiai Kar kiadványa; sorozatszerkesztő: Könczei Györgylde nem kellene valami adat: hely, év, kiadó stb.

7. Glassman P, Harrington M, Namakian M, Subar P: Interprofessional Collaboration in Improving Oral Health for Special Populations. Dent Clin North Am. 2016 Oct; 60 (4): 843-855.

8. Gordosné Sz A: Bevezető általános gyógypedagógiai ismeretek. Nemzeti Tankönyvkiadó, Budapest, 2004, 80-85.

9. Knapp P, Campbell Burton CA, Holmes J, Murray J, Gillespie D, LIGHTBODY CE, et al.: Interventions for treating anxiety after stroke, Cochrane Database Syst Rev. 2011 Dec 7; (12)

10. Kwok C, Mclntyre A, Jansen $S$, et al.: Oral care post stroke: a scoping review. J Oral Rehabil. 2015, 42 (1): 65-74.

11. Madléna M, Hermann $P$, Jáhn M, Fejérdy $P$ : Caries prevalence and tooth loss in Hungarian adult population: results of a national survey. BMC Public Health. 2008, 8: 364.

12. Moldval J, Orsós M, Simon F, Merész G, Németh O: Descriptive study of oral health, dental care and health behavior of inpatients undergoing physical medicine and rehabilitation. Oral Health Care. 2019 Ferb; 4: 4-4.

13. Németh O, Orsós M, Moldvai J, Kivovics P, Putz M, Cserháti P: Orvosi rehabilitációs kezelésben részesülő betegek orális egészsége. Rehabilitáció. 2018; 28 (4): 129-133.

14. Orsós M, Moldval J, Kivovics P, Németh O: Orvosi rehabilitációs kezelésben részesülő betegek orális egészségügyi állapotának vizsgálata Orv Hetil. 2018 Dec; 159 (52): 2202-2206.

15. Pakpour AH, Kumar S, Scheerman JFM, Lin C-Y, Fridlund B, Jansson $\mathrm{H}$ : Oral health-related quality of life in Iranian patients with spinal cord injury: A case-control study. Injury. 2016 Jun; 47 (6): 1345-1352.

16. PARK A, et al.: British social attitudes survey 23rd report. London, Sage, 2007.

17. Shah A, Naseem M, Khan M, Asiri F, AlQarni I, Gulzar $S$, et al.: Oral health knowledge and attitude among caregivers of special needs patients at a Comprehensive Rehabilitation Centre: an analytical study Ann Stomatol (Roma). 2017 Sep-Dec; 8 (3): 110-116.

18. U.S. Department of Health and Human Services: Oral health in America: a report of the Surgeon General. Rockville (MD): U.S. Department of Health and Human Services; National Institute of Dental and Craniofacial Research; National Institutes of Health, 2000.

19. http://www.ksh.hu/nepszamlalas/fogyatekossag_sb (2019.02.03.)

20. http://www.meosz.hu/wp-content/uploads/2018/04/11-22018.04.12EMMI-Egészségügyi-szolgáltatásokSzürvizsgálatokakadálymentesítése-válasz.pdf (2018.12.27)

21. http://www.who.int/disabilities/world_report/2011/report/en/ (2019.03.03.)

22. https://net.jogtar.hu/jr/gen/hjegy_doc.cgi?docid=99800026.TV (2019.03.03.)

23. https://www.gerodontology.com/content/uploads/2014/10/stroke_ guidelines (2019.03.04.)

24. https://www.palyazat.gov.hu/az_europai_bizottsag_altal_elfogadott operativ_programok_2014_20 (2019.02.05.)

25. https://www.who.int/classifications/icf/icfbeginnersguide.pdf (2019.04.02.)

\section{Orsós M, Moldval J, NÉmeth O}

\section{Oral health of people with special needs}

More than 1 billion people are estimated to live with some form of disability. These people are considered as a vulnerable group even from a dental point of view, since their compromised functions make the regular oral hygienic routine and also the professional dental management more difficult. Their oral hygiene is poor since the daily oral hygiene routine is compromised and the regular care of these patients with special needs has not been solved in dental practices.

Keywords: special needs, disability, loss of function, oral hygiene, dental rehabilitation 